\title{
BMJ Open Pioglitazone and cardiovascular outcomes in patients with insulin resistance, pre-diabetes and type 2 diabetes: a systematic review and meta-analysis
}

\author{
Hung-Wei Liao, ${ }^{1}$ Jeffrey L Saver, ${ }^{2}$ Yi-Ling Wu, ${ }^{3}$ Tso-Hsiao Chen, ${ }^{4}$ Meng Lee, ${ }^{5}$ \\ Bruce Ovbiagele 6
}

To cite: Liao H-W, Saver JL, Wu Y-L, et al. Pioglitazone and cardiovascular outcomes in patients with insulin resistance, pre-diabetes and type 2 diabetes: a systematic review and meta-analysis. BMJ Open 2017;7:e013927. doi:10.1136/bmjopen-2016013927

- Prepublication history and additional material is available. To view please visit the journal (http://dx.doi.org/ 10.1136/bmjopen-2016013927).

Received 18 August 2016 Revised 2 December 2016 Accepted 9 December 2016

CrossMark

For numbered affiliations see end of article.

Correspondence to Dr Meng Lee; menglee5126@gmail.com

\section{ABSTRACT}

Objectives: To evaluate the effect of pioglitazone in people with insulin resistance, pre-diabetes and type 2 diabetes.

Design and setting: Systematic review and metaanalysis of randomised, controlled trials.

Data sources: Literature searches were performed across PubMed, EMBASE, MEDLINE and Cochrane Central Register of Controlled Trials from 1966 to May 2016 to identify randomised, controlled trials with more than 1 year follow-up.

Outcome measures: Relative risk (RR) with $95 \% \mathrm{Cl}$ was used to evaluate the association between pioglitazone and the risk of major adverse cardiovascular events (MACE: composite of non-fatal myocardial infarction, non-fatal stroke and cardiovascular death) and safety outcomes, after pooling data across trials in a fixed-effects model. Results: Nine trials with 12026 participants were enrolled in the current meta-analysis. Pioglitazone therapy was associated with a lower risk of MACE in patients with pre-diabetes or insulin resistance (RR $0.77,95 \% \mathrm{Cl} 0.64$ to 0.93 ), and diabetes (RR 0.83, $95 \% \mathrm{Cl} 0.72$ to 0.97$)$. Risks of heart failure (RR 1.32; Cl 1.14 to 1.54 ), bone fracture (RR $1.52,95 \% \mathrm{Cl} 1.17$ to 1.99$)$, oedema (RR, 1.63; $\mathrm{Cl} 1.52$ to 1.75$)$ and weight gain (RR 1.60; $\mathrm{Cl} 1.50$ to 1.72) increased in pioglitazone group.

Conclusions: Pioglitazone was associated with reduced risk of MACE in people with insulin resistance, pre-diabetes and diabetes mellitus. However, the risks of heart failure, bone fracture, oedema and weight gain were increased.

\section{MANUSCRIPT}

People with type 2 diabetes mellitus, ${ }^{1}$ prediabetes $^{2}$ and insulin resistance ${ }^{3}{ }^{4}$ are more likely to develop myocardial infarction and stroke and have also associated metabolic abnormalities, such as lipid abnormalities,

\section{Strengths and limitations of this study}

Pioglitazone reduced major adverse cardiovascular events in people with insulin resistance, prediabetes and diabetes mellitus (DM).

- Pioglitazone increased risks of heart failure, oedema and weight gain.

- Pioglitazone reduced new-onset DM in insulin resistance and pre-diabetes people.

- The results were dominated by two large randomised controlled trials.

hypertension and chronic vascular inflammation, that are themselves significant cardiovascular risk factors. ${ }^{5} 6$

Pioglitazone is known to improve insulin sensitivity, glycaemic control, hypertension, dyslipidaemia and microalbuminuria in patients with diabetes mellitus. ${ }^{5}$ Furthermore, a prior meta-analysis found that pioglitazone reduced the risk of myocardial infarction, stroke and death compared to control drugs or placebo in patients with type 2 diabetes mellitus, but whether pioglitazone is beneficial in prevention of cardiovascular diseases among patients with pre-diabetes or insulin resistance was not addressed. ${ }^{7}$ Since then, several randomised controlled trials have been published to evaluate the effect of pioglitazone on occurrence of cardiovascular events in various types of patients. ${ }^{8-14}$ These trials comprised patients with insulin resistance, ${ }^{9}$ pre-diabetes (eg, impaired fasting glucose and/or impaired glucose tolerance $)^{810}$ or type 2 diabetes mellitus.

Therefore, to qualitatively and quantitatively evaluate the overall benefits (eg, major adverse cardiovascular events, myocardial infarction and stroke) and risks (eg, heart failure, fracture, all-cause mortality, cancer, 
bladder cancer, oedema, weight gain and hypoglycaemia) of pioglitazone therapy in patients with insulin resistance, pre-diabetes and type 2 diabetes, we conducted a systematic review and meta-analysis of relevant randomised controlled trials to date.

\section{METHODS}

The current meta-analysis was conducted in accordance with the recommendations of the Preferred Reporting Items for Systematic Reviews and Meta-Analysis: the PRISMA Statement. ${ }^{15}$

\section{Search strategy}

We searched PubMed (1966 to 17 May 2016), EMBASE and MEDLINE (1980 to 17 May 2016) and the Cochrane Central Register of Controlled Trials (1966 to 17 May 2016) using MESH terms and free text: "pioglitazone' or 'actos' AND 'diabetes mellitus' or 'glucose intolerance' or 'prediabetic state' or 'impaired glucose tolerance' or 'impaired fasting glucose' or 'insulin resistance'. We restricted the search to studies in humans and clinical trials using filters provided by PubMed and EMBASE. There was no language restriction. We retrieved further information by a manual search of references from recent reviews and relevant published original studies.

\section{Study selection and data abstraction}

Criteria for inclusion of this study were as follows: (1) the study design was a randomised controlled trial; (2) patients had the history of pre-diabetes or insulin resistance or type 2 diabetes mellitus; (3) the study included a comparison of pioglitazone with control (eg, placebo or other glucose-lowering agents); (4) total participants and the number of cardiovascular events (eg, composite of myocardial infarction and stroke, or either myocardial infarction and stroke) were reported separately for active treatment and control groups; (5) intended follow-up of at least 1 year for all participants. Any age or participants of either sex were included. All data from eligible studies were abstracted by two independent investigators (HWL and ML) according to a standard protocol. Discrepancies were resolved by discussion with a third investigator (YLW) and by referencing the original report. Recorded data variables were as follows: trial's name and first author's name, year of publication, country origin, population of participants, mean age, percentage women, baseline characteristics, duration of follow-up and number of participants and events for each group.

\section{Study quality assessment}

All the included studies were randomised controlled trials. The risk of bias (eg, selection bias, performance bias, detection bias, attrition bias and reporting bias) of the included trials was assessed by Cochrane risk-of-bias algorithm (http://www.cohchrane.org/training/cochranehandbook).

\section{Data synthesis and analysis}

Since pre-diabetes and diabetes do not confer the same risk for the different entities of cardiovascular disease, patients with insulin resistance/pre-diabetes and diabetes were analysed separately for cardiovascular outcomes. Insulin resistance was defined as a value of more than 3.0 on the homeostasis model assessment of insulin resistance (HOMA-IR) index. ${ }^{9}$ The HOMA-IR value was calculated as the level of fasting glucose (measured in millimoles per litre) times the level of fasting insulin (measured in microunits per millilitre) divided by 22.5. The primary end points were the association of pioglitazone therapy (compared with control) with risks for major adverse cardiovascular events (MACE). The definition of MACE was non-fatal myocardial infarction, nonfatal stroke and cardiovascular death. The secondary end points were myocardial infarction and stroke. Safety outcomes were heart failure, fracture, all-cause mortality, cancer, bladder cancer, oedema, weight gain and hypoglycaemia. We also analysed the effect of pioglitazone versus placebo on development of diabetes among people with pre-diabetes or insulin resistance, but not having frank diabetes mellitus, at baseline.

Relative risk (RR) with $95 \%$ CIs was used to estimate the risk of clinical outcomes between the pioglitazone group and the control group. All analyses were based on the intention-to-treat principle. We entered number of participants with events and total number of participants in the pioglitazone and control groups. We pooled data across trials using a fixed-effects model based on Mantel-Haenszel methods. Heterogeneity was assessed by $\mathrm{p}$ value of $\chi^{2}$ statistics and $\mathrm{I}^{2}$, which describes the percentage of variability in the effect estimates that is due to heterogeneity rather than to chance. Heterogeneity was considered if either the $\chi^{2}$ test was significant with the $\mathrm{p}=0.10$ level or the $\mathrm{I}^{2}$ statistic was $>50 \%$. Publication bias was assessed graphically using a funnel plot and mathematically using an adjusted rank-correlation test, according to the Begg and Mazumdar method.

To evaluate whether the present meta-analysis had sufficient sample size to reach firm conclusions about the effect of interventions, trial sequential analysis (TSA) was performed for the major outcomes. ${ }^{16}$ TSA performs accumulative meta-analysis, which creates $\mathrm{Z}$ curve of the summarised observed effect and the monitoring boundaries for benefit, harm and futility, and it estimates the required information size. These boundaries and analyses are adjusted to account for the amount of available evidence and to control for repeated analyses, while maintaining type I error at $5 \%$ and the power at $80 \%$. The required information size was calculated based on the event rate observed in the comparator group and the pioglitazone group. If the $\mathrm{Z}$ curve of the cumulative meta-analysis crosses one of the boundaries, no further studies are required and there is sufficient evidence to support the conclusions.

This meta-analysis was analysed by Cochrane Collaboration's Review Manager Software Package 
Table 1 Baseline characteristics of included trials

\begin{tabular}{|c|c|c|c|c|c|c|c|c|c|c|}
\hline Trial & $\begin{array}{l}\text { Publication } \\
\text { year/country }\end{array}$ & Population & Active/control & $\begin{array}{l}\text { Sample } \\
\text { sizel } \\
\text { women } \\
\text { (\%) }\end{array}$ & Age & $\begin{array}{l}\text { Baseline } \\
\text { HbA1c/ } \\
\text { fasting } \\
\text { glucose }\end{array}$ & BMI & $\begin{array}{l}\text { Statin, } \\
\%\end{array}$ & Antiplatelet, \% & $\begin{array}{l}\text { Anticoagulant, } \\
\%\end{array}$ \\
\hline ACT NOW ${ }^{8}$ & 2011/USA & $\begin{array}{l}\text { Age } \geq 18 \text { year, } \mathrm{BMI} \geq 25 \text {, } \\
\text { had a fasting plasma } \\
\text { glucose level between } 95 \\
\text { and } 125 \mathrm{mg} / \mathrm{dL}\end{array}$ & $\begin{array}{l}\text { Pioglitazone/ } \\
\text { placebo }\end{array}$ & $602 / 58$ & $\begin{array}{l}52.3 \\
\pm 0.5\end{array}$ & $\begin{array}{l}5.5 \pm 0.4 / \\
105 \pm 0.4\end{array}$ & $\begin{array}{l}33.7 \\
\pm 0.4\end{array}$ & NA & NA & NA \\
\hline CHICAGO $^{19}$ & 2006/USA & $\begin{array}{l}\text { 45-85 year, newly } \\
\text { diagnosed DM }\end{array}$ & $\begin{array}{l}\text { Pioglitazone/ } \\
\text { glimepiride }\end{array}$ & $458 / 37$ & $\begin{array}{l}59.6 \\
\pm 8.1\end{array}$ & $\begin{array}{l}7.4 \pm 1.0 / \\
150.7 \pm 50.0\end{array}$ & $\begin{array}{l}32.1 \\
\pm 5.1\end{array}$ & 55.2 & 45.6 & NA \\
\hline $\mathrm{IRIS}^{9}$ & $\begin{array}{l}\text { 2016/ } \\
\text { Multicounty }\end{array}$ & $\begin{array}{l}\text { Ischaemic stroke or TIA, } \\
\text { age } \geq 40 \text { year, insulin } \\
\text { resistance, excluded } \\
\text { patients with fasting } \\
\text { glucose } \geq 126 \mathrm{mg} / \mathrm{dL} \text { or } \\
\text { Hba } 1 \mathrm{c} \geq 7.0 \%\end{array}$ & $\begin{array}{l}\text { Pioglitazone/ } \\
\text { placebo }\end{array}$ & $3876 / 35$ & $\begin{array}{l}63.5 \\
\pm 10.6\end{array}$ & $\begin{array}{l}5.8 \pm 0.4 / \\
98.3 \pm 10.0\end{array}$ & $\begin{array}{l}30.0 \\
\pm 5.5\end{array}$ & 82.5 & 92.2 & 11.4 \\
\hline J-SPIRIT $^{10}$ & 2015/Japan & $\begin{array}{l}\text { Ischaemic stroke or TIA, } \\
\text { age } \geq 20 \text { year, IGT or } \\
\text { newly diagnosed DM }\end{array}$ & $\begin{array}{l}\text { Pioglitazone/diet } \\
\text { or other treatment }\end{array}$ & $120 / 24$ & $\begin{array}{l}68.4 \\
(40- \\
89)\end{array}$ & $6.0 \pm 0.4 / \mathrm{NA}$ & $\begin{array}{l}24.2 \\
\pm 3.3\end{array}$ & 44.2 & 84.2 & 15.8 \\
\hline Kaku et al ${ }^{11}$ & 2009/Japan & $\begin{array}{l}35-74 \text { year/old, DM, and } \\
\text { two of the risk factors } \\
\text { (hypertension, } \\
\text { hyperlipidaemia or } \\
\text { smoking) }\end{array}$ & $\begin{array}{l}\text { Pioglitazone/ } \\
\text { non-Pioglitazone } \\
\text { control }\end{array}$ & $587 / 37.5$ & 57.9 & $7.6 / 162$ & 26.72 & 45.0 & NA & NA \\
\hline Lee et al & 2013/Korea & $\begin{array}{l}\text { DM, ischaemic heart } \\
\text { disease undergo } \\
\text { percutaneous coronary } \\
\text { intervention (PCI) with } \\
\text { drug-eluting stents }\end{array}$ & $\begin{array}{l}\text { Pioglitazone/ } \\
\text { placebo }\end{array}$ & $121 / 26$ & $\begin{array}{l}61.1 \\
\pm 9.1\end{array}$ & $7.7 \pm 1.7 / \mathrm{NA}$ & $\begin{array}{l}23.9 \\
\pm 3.1\end{array}$ & 73.6 & $\begin{array}{l}\text { Clopidogrel: } 98 \\
\text { Cilostazol:30.6 }\end{array}$ & NA \\
\hline PERISCOPE ${ }^{13}$ & $\begin{array}{l}\text { 2008/North } \\
\text { and South } \\
\text { America }\end{array}$ & $\begin{array}{l}35-85 \text { year, DM , at least } \\
1 \text { coronary vessel with } \\
20 \% \text { to } 50 \% \text { obstruction }\end{array}$ & $\begin{array}{l}\text { Pioglitazone/ } \\
\text { glimepiride }\end{array}$ & $543 / 32.6$ & $\begin{array}{l}59.8 \\
\pm 9.2\end{array}$ & $\begin{array}{l}7.4 \pm 1.0 / \\
147.6 \pm 42.2\end{array}$ & $\begin{array}{l}32.0 \\
\pm 5.2\end{array}$ & 81.8 & Aspirin:90.8 & NA \\
\hline
\end{tabular}




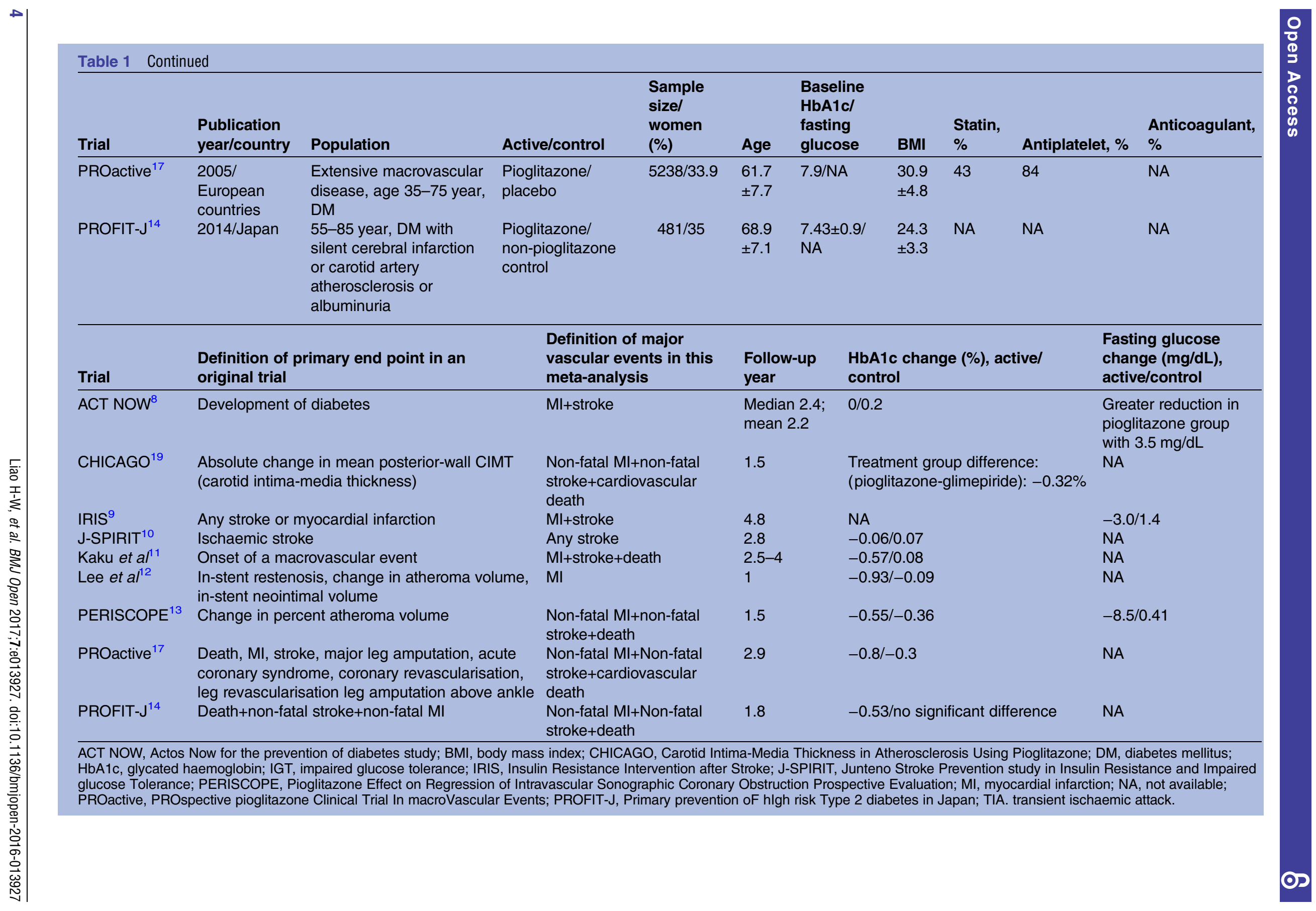

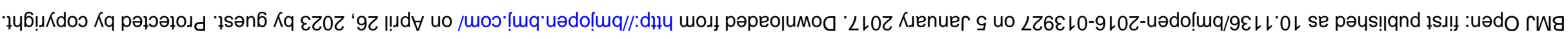




\begin{tabular}{|c|c|c|c|c|c|c|c|}
\hline Trial & $\begin{array}{l}\text { Random sequence } \\
\text { generation } \\
\text { (selection bias) }\end{array}$ & $\begin{array}{l}\text { Allocation } \\
\text { concealment } \\
\text { (selection bias) }\end{array}$ & $\begin{array}{l}\text { Blinding of participants } \\
\text { and personnel } \\
\text { (performance bias) }\end{array}$ & $\begin{array}{l}\text { Blinding of } \\
\text { outcome } \\
\text { assessment } \\
\text { (detection bias) }\end{array}$ & $\begin{array}{l}\text { Incomplete } \\
\text { outcome data } \\
\text { (attrition bias) }\end{array}$ & $\begin{array}{l}\text { Selective reporting } \\
\text { (reporting bias) }\end{array}$ & $\begin{array}{l}\text { Other } \\
\text { potential bias }\end{array}$ \\
\hline ACT NOW ${ }^{8}$ & $\begin{array}{l}\text { Unclear risk Quote: } \\
\text { randomised by } \\
\text { centre and gender } \\
\text { using block } \\
\text { randomisation } \\
\text { Comment: } \\
\text { insufficient } \\
\text { information about } \\
\text { the sequence } \\
\text { generation process }\end{array}$ & $\begin{array}{l}\text { Unclear risk } \\
\text { Comment: } \\
\text { insufficient } \\
\text { information }\end{array}$ & $\begin{array}{l}\text { Low risk Quote: } \\
\text { double-blind, } \\
\text { placebo-controlled } \\
\text { Comment: probably done }\end{array}$ & $\begin{array}{l}\text { Low risk Quote: } \\
\text { double blind } \\
\text { Comment: } \\
\text { probably done }\end{array}$ & $\begin{array}{l}\text { Low risk } \\
\text { Comment: } 9 \% \text { vs } \\
7 \% \text { patients lost } \\
\text { follow-up }\end{array}$ & $\begin{array}{l}\text { Low risk Comment: } \\
\text { study protocol is } \\
\text { available, and all of } \\
\text { the study's } \\
\text { prespecified outcomes } \\
\text { of interest in the } \\
\text { review have been } \\
\text { reported in the } \\
\text { prespecified way }\end{array}$ & $\begin{array}{l}\text { Low risk } \\
\text { Comment: } \\
\text { study seems to } \\
\text { be free of } \\
\text { other sources } \\
\text { of bias }\end{array}$ \\
\hline $\mathrm{CHICAGO}^{19}$ & $\begin{array}{l}\text { Unclear risk Quote: } \\
\text { received } \\
\text { randomised } \\
\text { treatment } \\
\text { Comment: } \\
\text { insufficient } \\
\text { information about } \\
\text { the sequence } \\
\text { generation process }\end{array}$ & $\begin{array}{l}\text { Unclear risk } \\
\text { Comment: } \\
\text { insufficient } \\
\text { information }\end{array}$ & $\begin{array}{l}\text { Low risk Quote: } \\
\text { double-blind, } \\
\text { comparator-controlled } \\
\text { Comment: probably done }\end{array}$ & $\begin{array}{l}\text { Low risk Quote: } \\
\text { double blind } \\
\text { Comment: } \\
\text { probably done }\end{array}$ & $\begin{array}{l}\text { Low risk } \\
\text { Comment: } 5 \% \text { vs } \\
3 \% \text { patients lost } \\
\text { follow-up }\end{array}$ & $\begin{array}{l}\text { Unclear risk } \\
\text { Comment: study } \\
\text { protocol is not } \\
\text { available, insufficient } \\
\text { information to permit } \\
\text { judgement }\end{array}$ & $\begin{array}{l}\text { Low risk } \\
\text { Comment: } \\
\text { study seems to } \\
\text { be free of } \\
\text { other sources } \\
\text { of bias }\end{array}$ \\
\hline $\mathrm{IRIS}^{9}$ & $\begin{array}{l}\text { Low risk Quote: } \\
\text { using a random } \\
\text { permuted block } \\
\text { design with variable } \\
\text { block sizes stratified } \\
\text { by site } \\
\text { Comment: probably } \\
\text { done }\end{array}$ & $\begin{array}{l}\text { Low risk Quote: } \\
\text { randomisation lists } \\
\text { were kept only at } \\
\text { the central } \\
\text { pharmacy and the } \\
\text { statistical centre } \\
\text { Comment: probably } \\
\text { done }\end{array}$ & $\begin{array}{l}\text { Low risk Quote: } \\
\text { double-blind, } \\
\text { placebo-controlled } \\
\text { Comment: probably done }\end{array}$ & $\begin{array}{l}\text { Low risk Quote: } \\
\text { double blind } \\
\text { Comment: } \\
\text { probably done }\end{array}$ & $\begin{array}{l}\text { Low risk } \\
\text { Comment: } 3 \% \text { vs } \\
2 \% \text { patients lost } \\
\text { follow-up }\end{array}$ & $\begin{array}{l}\text { Low risk Comment: } \\
\text { study protocol is } \\
\text { available, and all of } \\
\text { the study's } \\
\text { prespecified outcomes } \\
\text { of interest in the } \\
\text { review have been } \\
\text { reported in the } \\
\text { prespecified way }\end{array}$ & $\begin{array}{l}\text { Low risk } \\
\text { Comment: } \\
\text { study seems to } \\
\text { be free of } \\
\text { other sources } \\
\text { of bias }\end{array}$ \\
\hline J-SPIRIT ${ }^{10}$ & $\begin{array}{l}\text { Unclear risk Quote: } \\
\text { randomly assigned } \\
\text { Comment: } \\
\text { insufficient } \\
\text { information about } \\
\text { the sequence } \\
\text { generation process }\end{array}$ & $\begin{array}{l}\text { Unclear risk } \\
\text { Comment: } \\
\text { insufficient } \\
\text { information }\end{array}$ & $\begin{array}{l}\text { High risk Quote: } \\
\text { matching control group } \\
\text { (diet or other treatment) }\end{array}$ & $\begin{array}{l}\text { Unclear risk } \\
\text { Comment: } \\
\text { insufficient } \\
\text { information }\end{array}$ & $\begin{array}{l}\text { Low risk } \\
\text { Comment: } 8 \% \text { vs } \\
14 \% \text { patients lost } \\
\text { follow-up }\end{array}$ & $\begin{array}{l}\text { Unclear risk } \\
\text { Comment: study } \\
\text { protocol is not } \\
\text { available, insufficient } \\
\text { information to permit } \\
\text { judgement }\end{array}$ & $\begin{array}{l}\text { Low risk } \\
\text { Comment: } \\
\text { study seems to } \\
\text { be free of } \\
\text { other sources } \\
\text { of bias }\end{array}$ \\
\hline Kaku et al ${ }^{11}$ & $\begin{array}{l}\text { Unclear risk Quote: } \\
\text { were randomised } \\
\text { Comment: } \\
\text { insufficient }\end{array}$ & $\begin{array}{l}\text { Unclear risk } \\
\text { Comment: } \\
\text { insufficient } \\
\text { information } \\
\end{array}$ & $\begin{array}{l}\text { High risk Quote: } \\
\text { open-label }\end{array}$ & $\begin{array}{l}\text { Low risk Quote: } \\
\text { blinded-end } \\
\text { point }\end{array}$ & $\begin{array}{l}\text { Low risk } \\
\text { Comment: } 18 \% \text { vs } \\
12 \% \text { patients } \\
\text { missed some } \\
\end{array}$ & $\begin{array}{l}\text { Unclear risk } \\
\text { Comment: study } \\
\text { protocol is not } \\
\text { available, insufficient }\end{array}$ & $\begin{array}{l}\text { Low risk } \\
\text { Comment: } \\
\text { study seems to } \\
\text { be free of } \\
\end{array}$ \\
\hline
\end{tabular}


Table 2 Continued

\begin{tabular}{|c|c|c|c|c|c|c|c|}
\hline Trial & $\begin{array}{l}\text { Random sequence } \\
\text { generation } \\
\text { (selection bias) }\end{array}$ & $\begin{array}{l}\text { Allocation } \\
\text { concealment } \\
\text { (selection bias) }\end{array}$ & $\begin{array}{l}\text { Blinding of participants } \\
\text { and personnel } \\
\text { (performance bias) }\end{array}$ & $\begin{array}{l}\text { Blinding of } \\
\text { outcome } \\
\text { assessment } \\
\text { (detection bias) }\end{array}$ & $\begin{array}{l}\text { Incomplete } \\
\text { outcome data } \\
\text { (attrition bias) }\end{array}$ & $\begin{array}{l}\text { Selective reporting } \\
\text { (reporting bias) }\end{array}$ & $\begin{array}{l}\text { Other } \\
\text { potential bias }\end{array}$ \\
\hline & $\begin{array}{l}\text { information about } \\
\text { the sequence } \\
\text { generation process }\end{array}$ & & & $\begin{array}{l}\text { Comment: } \\
\text { probably done }\end{array}$ & $\begin{array}{l}\text { assessments } \\
\text { during the study }\end{array}$ & $\begin{array}{l}\text { information to permit } \\
\text { judgement }\end{array}$ & $\begin{array}{l}\text { other sources } \\
\text { of bias }\end{array}$ \\
\hline Lee et $a l^{12}$ & $\begin{array}{l}\text { Unclear risk Quote: } \\
\text { randomised study } \\
\text { Comment: } \\
\text { insufficient } \\
\text { information about } \\
\text { the sequence } \\
\text { generation process }\end{array}$ & $\begin{array}{l}\text { Unclear risk } \\
\text { Comment: } \\
\text { insufficient } \\
\text { information }\end{array}$ & $\begin{array}{l}\text { Unclear risk Comment: } \\
\text { insufficient information }\end{array}$ & $\begin{array}{l}\text { Unclear risk } \\
\text { Comment: } \\
\text { insufficient } \\
\text { information }\end{array}$ & $\begin{array}{l}\text { Low risk } \\
\text { Comment: no } \\
\text { patients lost } \\
\text { follow-up except } \\
\text { withdrew consent }\end{array}$ & $\begin{array}{l}\text { Unclear risk } \\
\text { Comment: study } \\
\text { protocol is not } \\
\text { available, insufficient } \\
\text { information to permit } \\
\text { judgement }\end{array}$ & $\begin{array}{l}\text { Unclear risk } \\
\text { Comment: } \\
\text { insufficient } \\
\text { information }\end{array}$ \\
\hline PERISCOPE $^{13}$ & $\begin{array}{l}\text { Low risk Quote: } \\
\text { using an interactive } \\
\text { voice response } \\
\text { system } \\
\text { Comment: probably } \\
\text { done }\end{array}$ & $\begin{array}{l}\text { Low risk Quote: } \\
\text { using an interactive } \\
\text { voice response } \\
\text { system } \\
\text { Comment: probably } \\
\text { done }\end{array}$ & $\begin{array}{l}\text { Low risk Quote: patients } \\
\text { and all study personnel } \\
\text { were blinded to treatment } \\
\text { Comment: probably done }\end{array}$ & $\begin{array}{l}\text { Low risk Quote: } \\
\text { patients and all } \\
\text { study personnel } \\
\text { were blinded to } \\
\text { treatment } \\
\text { Comment: } \\
\text { probably done }\end{array}$ & $\begin{array}{l}\text { Low risk } \\
\text { Comment: } 2 \% \text { vs } \\
1.5 \% \text { patients lost } \\
\text { follow-up }\end{array}$ & $\begin{array}{l}\text { Low risk Comment: } \\
\text { study protocol is not } \\
\text { available, but the } \\
\text { published reports } \\
\text { clearly include all } \\
\text { expected outcomes, } \\
\text { including those that } \\
\text { were prespecified }\end{array}$ & $\begin{array}{l}\text { Low risk } \\
\text { Comment: } \\
\text { study seems to } \\
\text { be free of } \\
\text { other sources } \\
\text { of bias }\end{array}$ \\
\hline PROactive $^{17}$ & $\begin{array}{l}\text { Low risk Quote: } \\
\text { randomisation } \\
\text { sequence was } \\
\text { generated... passed } \\
\text { on to the interactive } \\
\text { voice response } \\
\text { Comment: probably } \\
\text { done }\end{array}$ & $\begin{array}{l}\text { Low risk Quote: } \\
\text { allocation done by } \\
\text { the method of } \\
\text { randomised } \\
\text { permuted blocks } \\
\text { response system } \\
\text { Comment: probably } \\
\text { done }\end{array}$ & $\begin{array}{l}\text { Low risk Quote: all } \\
\text { investigators and study } \\
\text { personnel were } \\
\text { unaware of treatment } \\
\text { assignment Comment: } \\
\text { probably done }\end{array}$ & $\begin{array}{l}\text { Low risk Quote: } \\
\text { all investigators } \\
\text { and study } \\
\text { personnel were } \\
\text { unaware of } \\
\text { treatment } \\
\text { assignment } \\
\text { Comment: } \\
\text { probably done }\end{array}$ & $\begin{array}{l}\text { Low risk } \\
\text { Comment: }<0.1 \% \\
\text { patients lost } \\
\text { follow-up }\end{array}$ & $\begin{array}{l}\text { Low risk Comment: } \\
\text { study protocol is } \\
\text { available, and all of } \\
\text { the study's } \\
\text { prespecified outcomes } \\
\text { of interest in the } \\
\text { review have been } \\
\text { reported in the } \\
\text { prespecified way }\end{array}$ & $\begin{array}{l}\text { Low risk } \\
\text { Comment: } \\
\text { study seems to } \\
\text { be free of } \\
\text { other sources } \\
\text { of bias }\end{array}$ \\
\hline PROFIT-J ${ }^{14}$ & $\begin{array}{l}\text { Unclear risk Quote: } \\
\text { randomise } \\
\text { Comment: } \\
\text { insufficient } \\
\text { information about } \\
\text { the sequence } \\
\text { generation process }\end{array}$ & $\begin{array}{l}\text { Unclear risk } \\
\text { Comment: } \\
\text { Insufficient } \\
\text { information }\end{array}$ & $\begin{array}{l}\text { High risk Quote: open } \\
\text { label }\end{array}$ & $\begin{array}{l}\text { High risk Quote: } \\
\text { open label }\end{array}$ & $\begin{array}{l}\text { Low risk } \\
\text { Comment: } 6 \% \\
\text { patients missed } \\
\text { some } \\
\text { assessments } \\
\text { during the study }\end{array}$ & $\begin{array}{l}\text { Low risk Comment: } \\
\text { study protocol is not } \\
\text { available, but the } \\
\text { published reports } \\
\text { clearly include all } \\
\text { expected outcomes, } \\
\text { including those that } \\
\text { were prespecified }\end{array}$ & $\begin{array}{l}\text { Low risk } \\
\text { Comment: } \\
\text { study seems to } \\
\text { be free of } \\
\text { other sources } \\
\text { of bias }\end{array}$ \\
\hline
\end{tabular}




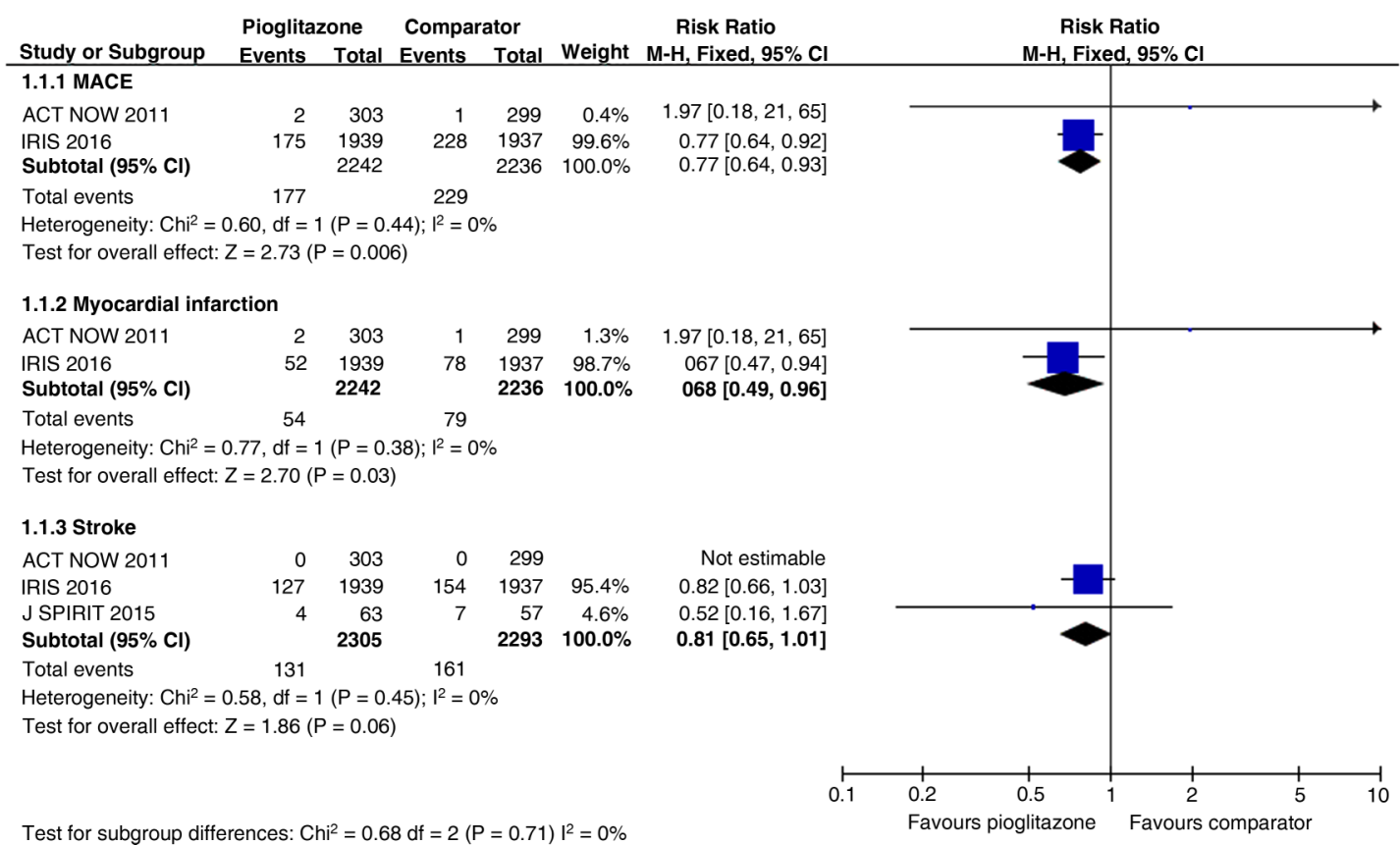

Figure 1 Separate and pooled relative risk and $95 \%$ Cls estimates for cardiovascular outcomes among patients with pre-diabetes or insulin resistance (pioglitazone vs control).

(RevMan 5.3). The Begg and Egger tests and the trim-and-fill tests were conducted using Stata V.12.0. The empirical continuity correction and TSA were conducted using TSA software V.0.9 ( $\beta)$.

\section{RESULTS}

Literature search identified 2956 articles and 2945 were excluded by reviewing topics or abstracts. The literature review identified $11^{8-14} \quad 17-20$ articles for detailed assessment (see online supplementary figure 1). One study was excluded because the study period was $<1$ year. ${ }^{18}$ Our final primary analysis included 10 articles derived from 9 randomised controlled trials. ${ }^{8-14} 171920$ A total of 12026 individuals were eligible, with mean age 61.8 \pm 9.0 years, and of whom $36 \%$ were women. About 5997 $(50 \%)$ participants were randomly assigned to the pioglitazone group and $6029(50 \%)$ participants were randomly assigned to the control group. The baseline characteristics and design of the included trials were summarised in table 1. All enrolled individuals had a history of insulin resistance, impaired glucose tolerance test or type 2 diabetes mellitus. The studies included participants with or without prior cardiovascular diseases. Two studies (IRIS, J-SPIRIT) ${ }^{9} 10$ enrolled only participants with a stroke or transient ischaemic attack, while in the other studies the majority of participants had not experienced a stroke or transient ischaemic attack at the time of study entry. The number of participants ranged from 121 to 5238. The mean study duration was 2.7 years (ranged from 1 to 4.8 years). The assessment of risk of bias is shown in table 2. Three trials had high risks of performance bias and detection bias because they were non-blinded. ${ }^{1011} 14$

\section{Cardiovascular outcomes}

Among patients with pre-diabetes or insulin resistance, pioglitazone was associated with lower risks of MACE (2 trials; RR 0.77 , 95\% CI 0.64 to 0.93 ; $\mathrm{p}$ for heterogeneity $=0.44, \mathrm{I}^{2}=0 \%$ ) and myocardial infarction (2 trials; RR $0.68,95 \%$ CI 0.49 to $0.96 ; p$ for heterogeneity $=0.38$, $\left.\mathrm{I}^{2}=0 \%\right)$. Pioglitazone was associated with a trend towards reducing recurrent stroke risk among patients with prediabetes or insulin resistance (2 trials; RR $0.81,95 \%$ CI 0.65 to 1.01 ; $\mathrm{p}$ for heterogeneity $=0.45, \mathrm{I}^{2}=0 \%$ ) (figure 1 ). Since data were only available in two trials for each end point, publication bias could not be evaluated. TSA was conducted by using fixed effects mode and showed the number of patients evaluated MACE $(n=4478)$, myocardial infarction $(n=4478)$ and stroke $(n=4598)$ did not surpass the required information sizes $(n=4687$ for MACE, n=7213 for myocardial infarction and n=10 398 for stroke) (figure 2).

Among patients with diabetes mellitus, pioglitazone was associated with a lower risk of MACE ( 5 trials; RR 0.83 , $95 \%$ CI 0.72 to 0.97 ; $p$ for heterogeneity $=0.87, \mathrm{I}^{2}=0 \%$ ). The risks of myocardial infarction ( 5 trials; RR $0.80,95 \%$ CI 0.62 to $1.03 ; \mathrm{p}$ for heterogeneity $=0.78, \mathrm{I}^{2}=0 \%$ ) and stroke ( 5 trials; RR $0.78,95 \%$ CI 0.60 to 1.02 ; p for heterogeneity $=0.90, \quad \mathrm{I}^{2}=0 \%$ ) were not significantly different between pioglitazone and comparator groups (figure 3). There was no publication bias in end points of MACE ( $p=0.88)$, myocardial infarction $(p=0.80)$ and stroke $(p=0.06)$, respectively. TSA was conducted by using fixed effects mode and showed that the number of patients evaluated for MACE $(\mathrm{n}=7307)$, myocardial infarction $(\mathrm{n}=6841)$ and stroke $(n=6840)$ did not surpass the required information sizes ( $\mathrm{n}=10578$ for MACE, $\mathrm{n}=17733$ for myocardial infarction and n=16 379 for stroke; figure 4). 
Figure 2 Trial sequential analysis for (A) MACE, (B) myocardial infarction, (C) stroke, among patients with pre-diabetes or insulin resistance. (A) A full blue cumulative Z-curve did not cross the required information size boundary but did cross boundary for benefit. (B) and (C) the required information size has not been reached and none of the boundaries for benefit, harm or futility has been crossed. MACE, major adverse cardiovascular events.
A

Required information size is a Two-sided graph

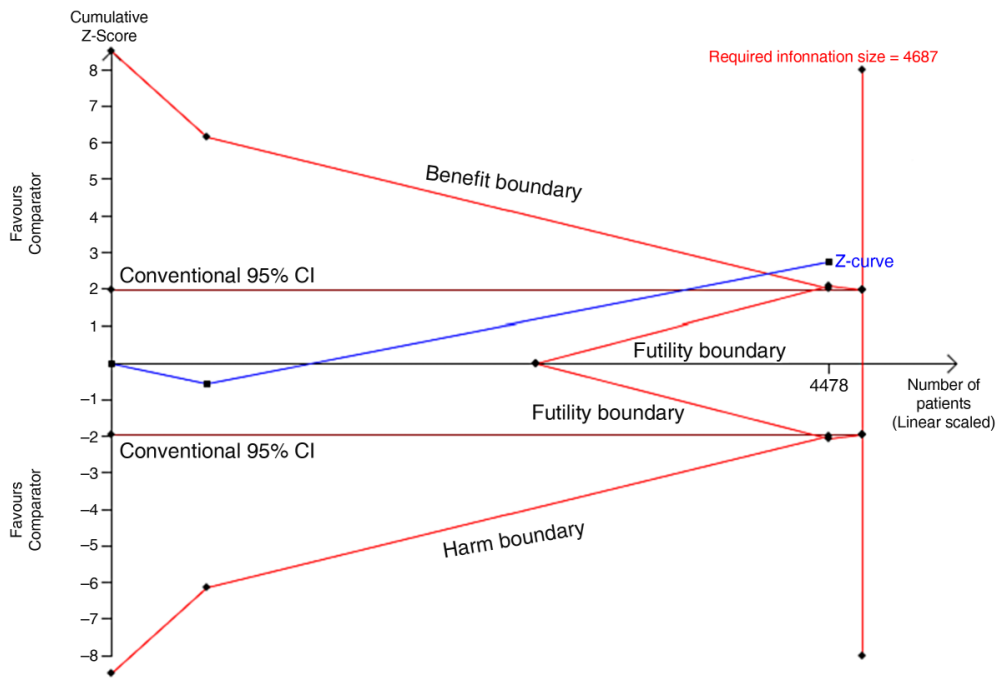

B

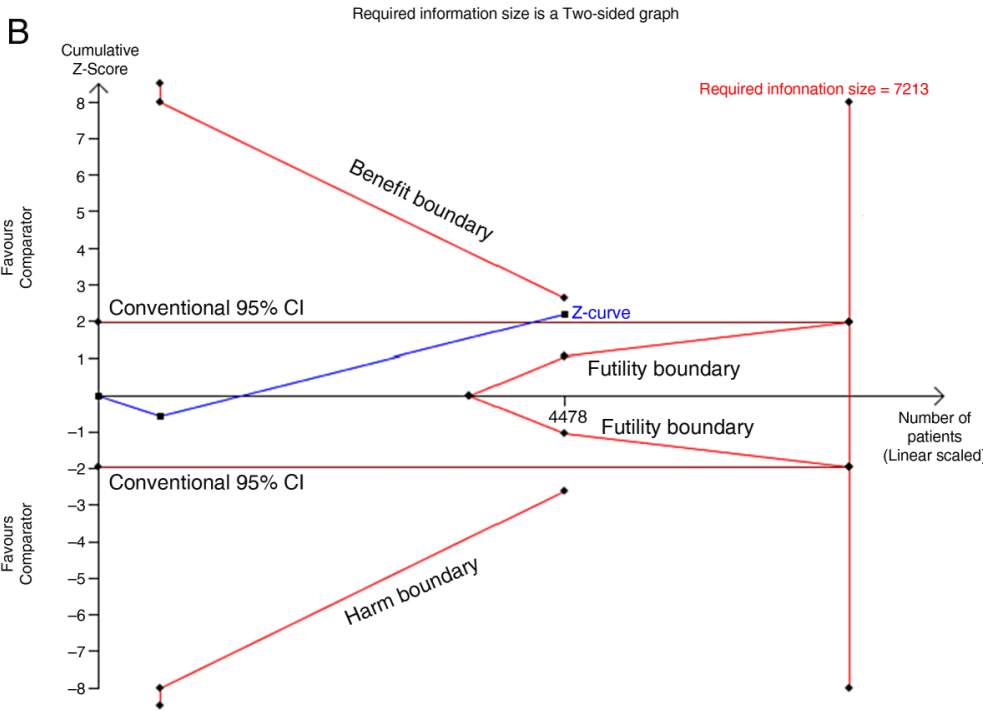

C

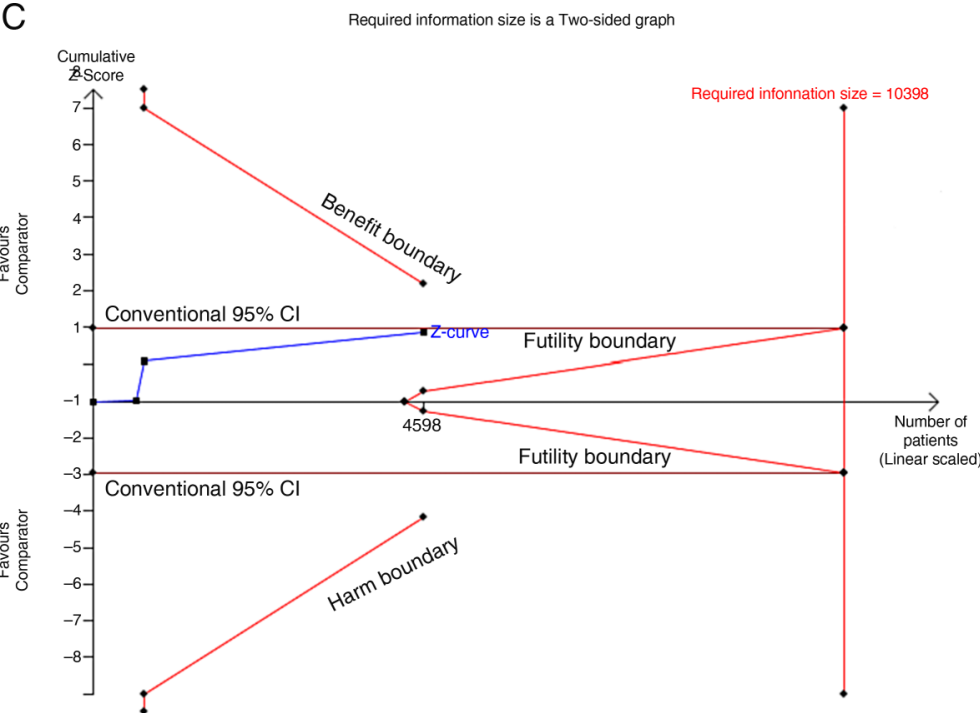




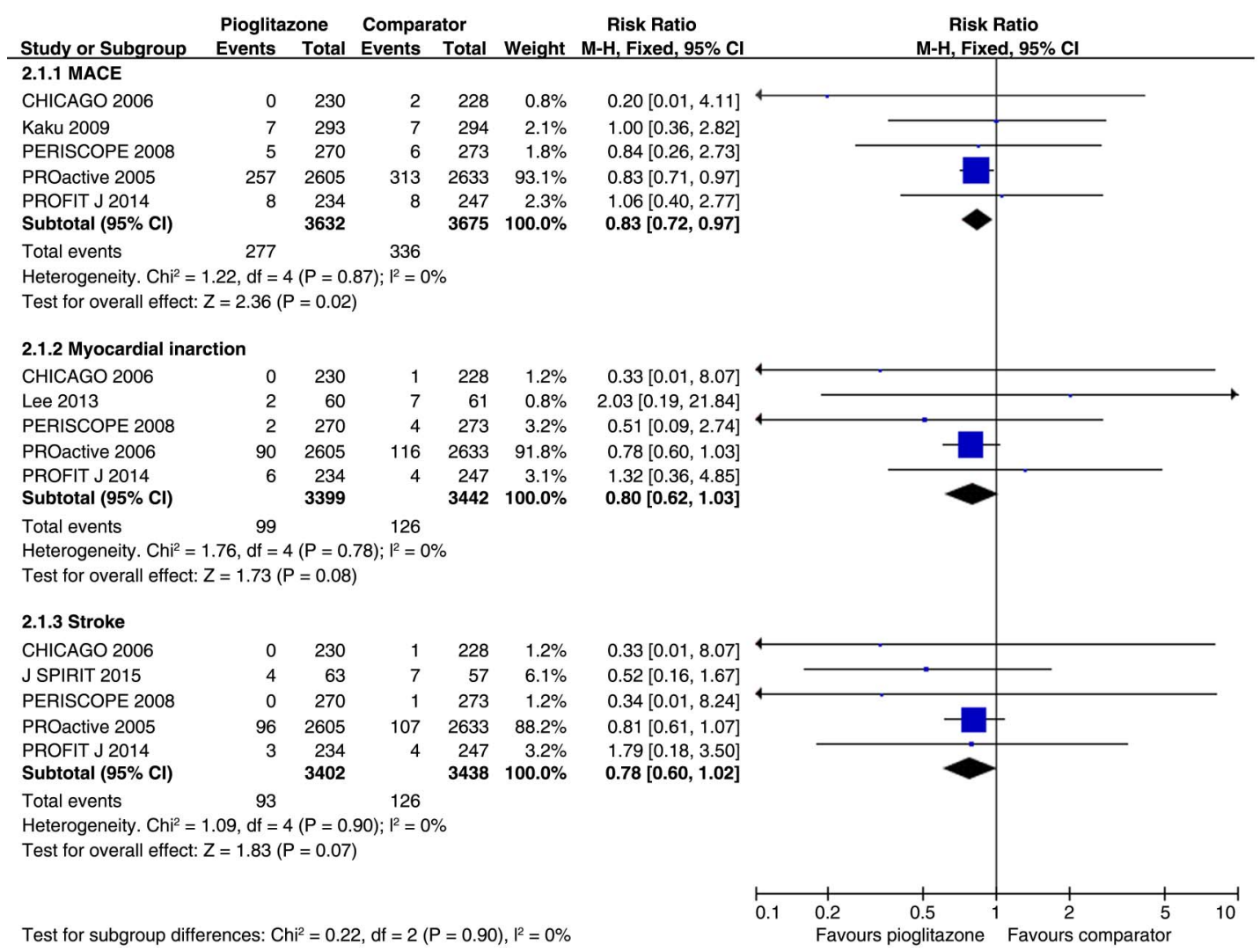

Figure 3 Separate and pooled relative risk and 95\% Cls estimates for cardiovascular outcomes among patients with type 2 diabetes mellitus (pioglitazone vs control).

\section{Safety outcomes}

Pioglitazone, as compared to control group, was associated with increased risk of heart failure (5 trials; RR $1.32,95 \%$ CI 1.14 to $1.54 ; \mathrm{p}$ for heterogeneity $=0.43$, $\mathrm{I}^{2}=0 \%$ ) and bone fracture (4 trials; RR $1.52,95 \%$ CI 1.17 to $1.99 ; \mathrm{p}$ for heterogeneity $=0.18, \mathrm{I}^{2}=39 \%$ ). There was no significant difference in the rate of all-cause mortality ( 7 trials; RR $0.93,95 \%$ CI 0.80 to 1.09 ; $\mathrm{p}$ for heterogeneity $=0.88, \mathrm{I}^{2}=0 \%$ ). Also, there was no significant difference in future any cancer (4 trials; RR 0.91, CI 0.77 to 1.08 ; $\mathrm{p}$ for heterogeneity $=0.44, \mathrm{I}^{2}=0 \%$ ) and bladder cancer risks (2 trials; RR 1.87, CI 0.98 to 3.57; p for heterogeneity $\left.=0.50, \mathrm{I}^{2}=0 \%\right)$. The Pioglitazone group had higher risk of oedema ( 7 trials; RR 1.63 , CI 1.52 to 1.75 ; $\mathrm{p}$ for heterogeneity $\left.=0.001, \mathrm{I}^{2}=0 \%\right)$, weight gain $(4$ trials; RR 1.60, CI 1.50 to 1.72; $\mathrm{p}$ for heterogeneity $=0.04$, $\mathrm{I}^{2}=64 \%$ ) and hypoglycaemia ( 5 trials; RR 1.24 , CI 1.13 to 1.35; $\mathrm{p}$ for heterogeneity $<0.00001, \mathrm{I}^{2}=93 \%$ ) (figure 5). There was no publication bias in end points of heart failure $(p=0.58)$, bone fracture $(p=0.77)$, all-cause mortality $(\mathrm{p}=0.47)$, any cancer $(\mathrm{p}=0.24)$, oedema $(\mathrm{p}=0.09)$, weight gain $(\mathrm{p}=0.40)$, and hypoglycaemia $(\mathrm{p}=0.37)$. TSA was conducted by using fixed effects mode and showed that the number of patients evaluated for all-cause mortality $(n=11319)$, any cancer $(n=10197)$, bladder cancer $(\mathrm{n}=9114)$ and hypoglycaemia $(\mathrm{n}=10 \mathrm{702})$ did not surpass the required information size $(n=129249$ for all-cause mortality, n=76 738 for any cancer, n=20 346 for bladder cancer and n=183 329 for hypoglycaemia).

The rate of progression to diabetes was significantly lower in the pioglitazone group than in the placebo group among people with pre-diabetes or insulin resistance (2 trials; RR $0.40,95 \%$ CI 0.25 to 0.65 ; $p$ for heterogeneity $=0.11) .{ }^{89}$

\section{DISCUSSION}

Our meta-analysis including 9 randomised controlled trials with over 120100 participants found that adding pioglitazone to standard therapy was associated with a 23\% risk reduction of MACE among patients with insulin resistance or pre-diabetes and $17 \%$ risk reduction of MACE among patients with type 2 diabetes mellitus. The results of our analysis suggest that the cardiovascular event reduction seen with pioglitazone among patients with diabetes mellitus is also seen among patients with insulin resistance or pre-diabetes. Also, pioglitazone use in people with pre-diabetes or insulin resistance, but not having frank diabetes mellitus at baseline, significantly reduced new-onset diabetes mellitus. However, pioglitazone use was associated with increased risks of heart failure, bone fracture, oedema and weight gain.

The exact mechanism underlying the cardiovascular risk reduction benefit of pioglitazone is not clear. It 
Figure 4 Trial sequential analysis for (A) MACE, (B) myocardial infarction, (C) stroke, among patients with diabetes mellitus. (A), (B) and (C): the required information size has not been reached and none of the boundaries for benefit, harm or futility has been crossed. MACE, major adverse cardiovascular events.
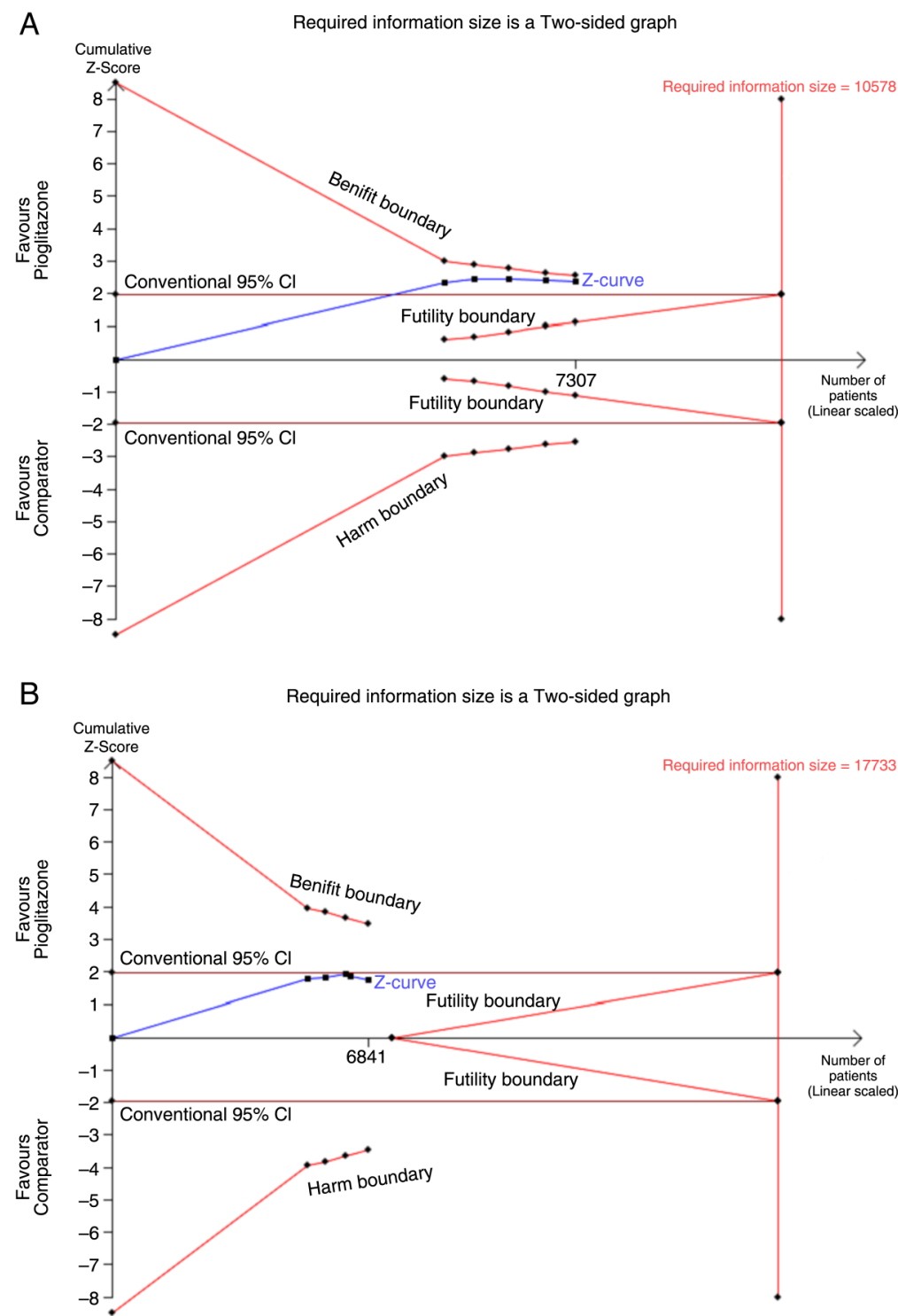

C

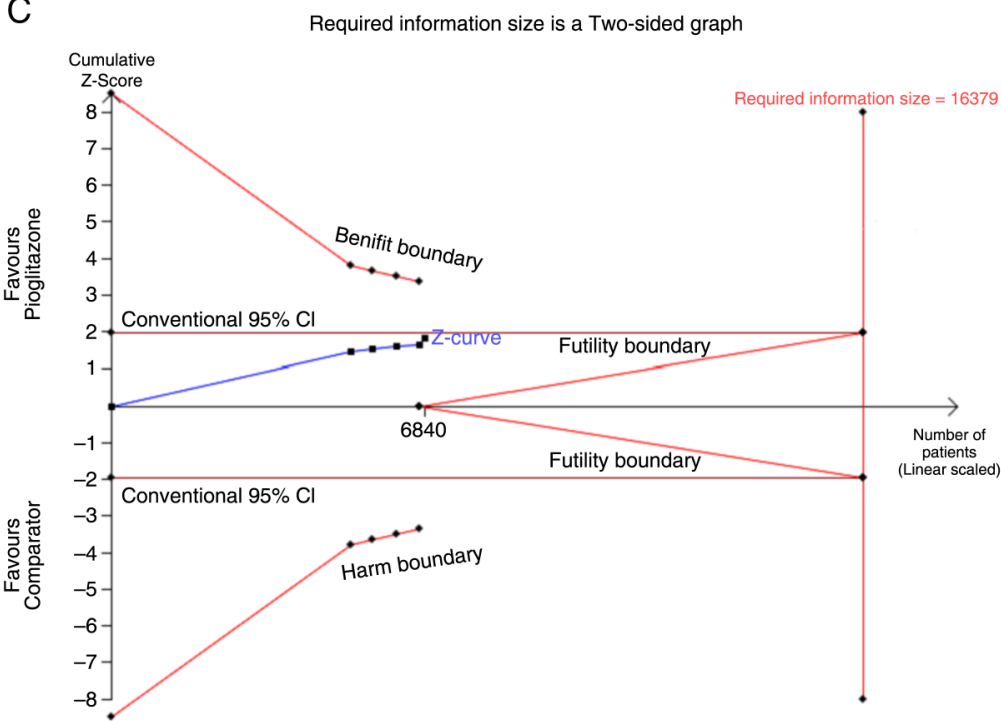


Figure 5 Separate and pooled relative risk and $95 \% \mathrm{Cls}$ estimates for safety outcomes among all included trials (pioglitazone vs control).

Experimental Control

Risk Ratio

Risk Ratio

\begin{tabular}{lrrrrrr} 
Study or Subgroup & Events & Total & Events & Total & Weight & M-H, Fixed, 95\% Cl \\
\hline 3.1.1 Heart failure & & & & & & \\
ACT NOW 2011 & 1 & 303 & 1 & 299 & $0.4 \%$ & $0.99[0.06,15.70]$ \\
CHICAGO 2006 & 1 & 230 & 0 & 228 & $0.2 \%$ & $2.97[0.12,72.62]$ \\
IRIS 2016 & 74 & 1939 & 71 & 1937 & $25.9 \%$ & $1.04[0.76,1.43]$ \\
PERISCOPE 2008 & 4 & 270 & 5 & 273 & $1.8 \%$ & $0.81[0.22,2.98]$ \\
PROaclive 2005 & 281 & 2605 & 198 & 2633 & $71.8 \%$ & $1.43[1.21,1.71]$ \\
Subtotal (95\% Cl) & & $\mathbf{5 3 4 7}$ & & $\mathbf{5 3 7 0}$ & $\mathbf{1 0 0 . 0 \%}$ & $1.32[1.14,1.54]$ \\
Total evenls & 361 & & 275 & 275 & &
\end{tabular}

\section{Total evenls}

361 $275 \quad 275$

$.32[1.14,1.54]$

Heterogeneity: $\mathrm{Chi}^{2}=3.83, \mathrm{df}=4(\mathrm{P}=0.43) ; \mathrm{l}^{2}=0 \%$

Test for overall effect: $Z=3.64(P=0.0003)$

$\begin{array}{lrr}\text { 3.1.2 Fracture } & & \\ \text { ACT NOW 2011 } & 8 & 3.3 \\ \text { IRIS 2016 } & 99 & 193 \\ \text { Kaku 2009 } & 18 & 293 \\ \text { PERISCOPE 2008 } & 8 & 270 \\ \text { Subtotal (95\% Cl) } & & 280 \\ \text { Total evenls } & 133 & \end{array}$

Total evenls

133

3.3
1939
293
270
2805

$\begin{array}{lll}2 & 1937 & 70.9 \%\end{array}$

$\begin{array}{lll}18 & 294 \quad 20.5 \%\end{array}$

$1.13[0.41,3.07]$

$.60[1.17,2.18]$

$.00[0.53,1.89]$

$\begin{array}{rrrr}0 & 273 & 0.6 \% & 17.19[1.00,296.32] \\ & 2803 & 100.0 \% & 1.52[1.17,1.99]\end{array}$

Heterogeneity: $\mathrm{Chi}^{2}=4.89, \mathrm{df}=3(\mathrm{P}=0.18) ; \mathrm{l}^{2}=39 \%$

Test for overall effect: $Z=3.13(P=0.002)$

3.1.3 All-cause mortality

CHICAGO 2006

IRIS 2016

Lee 2013

PERISCOPE 2008

PROactive 2005

PROFIT J 2014

$\begin{array}{ll}3 & 303 \\ 1 & 230\end{array}$

$\begin{array}{lll}1 & 299 & 0.3 \%\end{array}$

$0 \quad 228 \quad 0.2 \%$

$\begin{array}{lllll}136 & 1939 & 146 & 1937 & 49.6 \%\end{array}$

$\begin{array}{rrrrr}0 & 60 & 1 & 61 & 0.5 \%\end{array}$

$\begin{array}{rrrrr}3 & 270 & 2 & 273 & 0.7 \%\end{array}$

Subtotal (95\% Cl)

$129 \quad 2605$

$\begin{array}{lll}142 & 2633 & 48.0 \%\end{array}$

Total events

273

\begin{tabular}{rrrr}
234 & 2 & 247 & $0.7 \%$ \\
\hline 5641 & & 5678 & $100.0 \%$
\end{tabular} 294

Heterogeneity: $\mathrm{Chi}^{2}=2.42, \mathrm{df}=6(\mathrm{P}=0.88) ;\left.\right|^{2}=0 \%$

Test for overall effect: $Z=0.85(P=0.40)$

3.1.4 Any cancer

ACT NOW 2011

IRIS 2016

PROactive 2005

PROFIT J 2014

Subtotal $(95 \% \mathrm{Cl})$

Total events

$\begin{array}{lllll}3 & 303 & 8 & 299 & 3.0 \%\end{array}$

$\begin{array}{lllll}133 & 1939 & 150 & 1937 & 56.5 \%\end{array}$

$\begin{array}{lllll}103 & 2605 \quad 103 \quad 2633 \quad 38.6 \%\end{array}$

$\begin{array}{rrrrr}3 & 234 & 5 & 247 & 1.8 \% \\ & \mathbf{5 0 8 1} & & \mathbf{5 1 1 6} & \mathbf{1 0 0 . 0}\end{array}$

242 266

Heterogeneity: $\mathrm{Chi}^{2}=2.68, \mathrm{df}=3(\mathrm{P}=0.44) ; \mathrm{l}^{2}=0 \%$

Test for overall effect: $Z=1.05(P=0.30)$

3.1.5 Bladder cancer

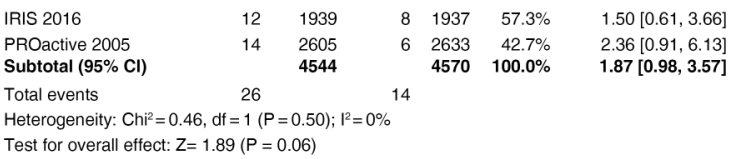

est for overall effect: $Z=1.89(P=0.06)$

3.1.6 Edema

ACT NOW 2011

CHICAGO 2006

IRIS 2016

Kaku 2009

PERISCOPE 2008

PROactive 2005

PROFIT J 2014

Subtotal $(95 \% \mathrm{Cl})$

Total events

$\begin{array}{lllll}39 & 303 & 19 & 299 & 2.0 \%\end{array}$

$2.03[1.20,3.42]$

$1.86[1.04,3.31]$

$1.43[1.30,1.58]$

$\begin{array}{rrrrrrr}48 & 293 & 12 & 294 & 1.3 \% & 4.01[2.18,7.40] \\ 48 & 270 & 30 & 273 & 3.1 \% & 1.62[1.06,2.47] \\ 689 & 2605 & 397 & 2633 & 41.3 \% & 1.75[1.57,1.96]\end{array}$

$\begin{array}{rrrrrrr}48 & 293 & 12 & 294 & 1.3 \% & 4.01[2.18,7.40] \\ 48 & 270 & 30 & 273 & 3.1 \% & 1.62[1.06,2.47] \\ 689 & 2605 & 397 & 2633 & 41.3 \% & 1.75[1.57,1.96]\end{array}$

$\begin{array}{llllll}689 & 2605 & 397 & 2633 & 41.3 \% & 1.75[1.57,1.96]\end{array}$

$\begin{array}{rrrrr}234 & 0 & 247 & 0.1 \% & 26.38[1.57,443.09] \\ \mathbf{5 8 7 4} & & \mathbf{5 9 1 1} & \mathbf{1 0 0 . 0} \% & 1.63[1.52, \mathbf{1 . 7 5}]\end{array}$

Heterogeneity: $\mathrm{Chi}^{2}=21.65, \mathrm{df}=6(\mathrm{P}=0.001) ; \mathrm{I}^{2}=72^{\circ}$

Test for overall effect: $Z=13.62(P<0.00001)$

3.1.7 Weight gain

ACT NOW 2011

CHICAGO 2006

IRIS 2016

PROaclive 2005

Subtotal $(95 \% \mathrm{Cl})$

$\begin{array}{llll}205-303 & 128 & 299 & 15.6 \%\end{array}$

\begin{tabular}{lll}
$10 \quad 228 \quad 1.2 \%$ \\
\hline
\end{tabular}

$\begin{array}{llll}1939 & 653 & 1937 & 79.0 \%\end{array}$

$\begin{array}{rrrrr}95 & 2605 & 35 & 2633 & 4.2 \%\end{array}$

$\mathbf{5 0 7 7} \quad \mathbf{5 0 9 7} \quad \mathbf{1 0 0 . 0 \%}$

Total events

1328

$826 \quad 826$

Heterogeneity: $\mathrm{Chi}^{2}=8.38, \mathrm{df}=3(\mathrm{P}=0.04) ; \mathrm{l}^{2}=64 \%$

Test for overall effect: $Z=13.76(P<0.00001)$

3.1.8 Hypoglycemia

CHICAGO 2006

IRIS 2016

Kaku 2009

PERISCOPE 2008

PROactive 2005

Subtotal $(95 \% \mathrm{Cl})$

Total events

$\begin{array}{rr}45 & 230 \\ 1 & 1939 \\ 46 & 293 \\ 41 & 270 \\ 709 & 2605 \\ & \mathbf{5 3 3 7}\end{array}$

$\begin{array}{lll}53 & 228 & 7.8 \%\end{array}$

$\begin{array}{lll}0 & 1937 & 0.1 \%\end{array}$

$38 \quad 294 \quad 5.6 \%$

$\begin{array}{lll}01 \quad 273 & 14.7 \%\end{array}$

$94 \quad 2633 \quad 71.9 \%$

$5365 \quad 100.0 \%$

842 686

Heterogeneity: $\mathrm{Chi}^{2}=59.57, \mathrm{df}=4(\mathrm{P}=0.00001) ; \mathrm{l}^{2}=93^{\circ}$

Test for overall effect: $Z=4.70(P<0.00001)$

Test for subgroup differences: $\left.\mathrm{Chi}^{2}=91.21 \mathrm{df}=7(\mathrm{P}<0.00001) \mathrm{P}^{2}=92.3 \%\right)$

$1.58[1.36,1.84]$

$1.49[0.68,3.24]$

$1.55[1.44,1.67]$

$2.74[1.87,4.03]$

$1.60[1.50,1.72]$

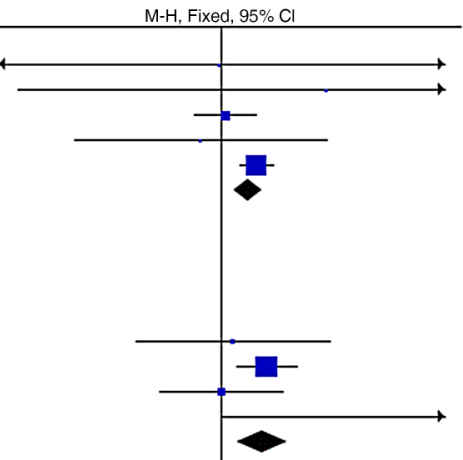


would seem unlikely to be simply its hypoglycaemic effect. $^{21-23}$ Since the pathogenesis of atherosclerosis is multifactorial involving dyslipidaemia, oxidation of lipoprotein and interactions of inflammatory cell, ${ }^{24}$ it more likely that the benefit of pioglitazone in cardiovascular event risk reduction is due to its several pleiotropic effects. For instance, favourable effects of pioglitazone use on the triglyceride/high-density lipoprotein-cholesterol ratio correlated with delayed atheroma progression in patients with diabetes. ${ }^{25}$ Also, cholesterol efflux capacity was inversely associated with the incidence of cardiovascular events in a population-based cohort ${ }^{26}$ and treatment with pioglitazone for 12 weeks significantly increased the cholesterol efflux capacity. ${ }^{27}$ In a study using serial (18) F-fluorodeoxyglucose positron emission tomography imaging to evaluate atherosclerotic plaque inflammation, pioglitazone attenuated atherosclerotic plaque inflammation in patients with impaired glucose tolerance or in patients with diabetes. ${ }^{28}$ However, the observed cardiovascular benefits of pioglitazone cannot be simply explained by a thiazolidinedione 'class effect', since another agent in this class, rosiglitazone, has been associated with an increased risk of cardiovascular events in several meta-analyses. ${ }^{29} 30$

There are several safety considerations in use of pioglitazone and we assessed safety outcomes in the present meta-analysis. Fluid retention, weight gain and heart failure are the most concerned adverse effects when patients receive thiazolidinedione compounds. In the current meta-analysis, the risk of heart failure, oedema and weight gain increased in the pioglitazone treatment group. Certain strategies such as excluding patients with a prior heart failure and using safety algorithms that triggered dose reduction for excessive oedema or weight gain may be helpful to reduce the incidence of heart failure in patients receiving pioglitazone therapy. ${ }^{9}$

We found that pioglitazone use was associated with increased risks of bone fracture. A meta-analysis of randomised controlled trials showed that treatment with thiazolidinediones resulted in modest bone loss. ${ }^{31}$ One study suggested thiazolidinediones increased bone fracture in women, but not in men, ${ }^{32}$ while other studies suggest that both sexes are similarly affected. ${ }^{33}$ However, the two included trials in our current analysis, with predominantly with men (>60\% of participants) both showed pioglitazone use substantially increased risk of bone fracture. ${ }^{9} 13$

Peroxisome proliferator activated receptor- $\gamma$ may play a role in carcinogenesis ${ }^{34}$ and the risk of cancer is a concern when thiazolidinedione is prescribed. Several studies $^{35} 36$ and a meta-analysis ${ }^{37}$ reported that pioglitazone increased the risk of bladder cancer while other

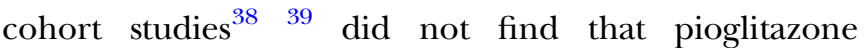
increased the risk of bladder cancer or other common cancers. In the analysis of our included trials that had reported the incidence of any cancer, the risk of cancer in pioglitazone-treated patients was not increased. However, only a few trials reported a cancer end point in our study and the risk of cancer when using pioglitazone needs to be further clarified.

This meta-analysis suggested that pioglitazone use reduced progression to diabetes mellitus in patients with impaired glucose tolerance ${ }^{8}$ and insulin resistance population $^{9}$ which is in consistent with findings from a prior study. ${ }^{40}$ Since diabetes mellitus is a major cardiovascular risk factor, avoiding or delaying onset of diabetes mellitus with pioglitazone treatment probably helped to prevent the development of macrovascular complications.

There are several limitations in this study. First, this meta-analysis was not registered in PROSPERO. Second, the results of this analysis dominated by two trials: IRIS $^{9}$ and PROactive ${ }^{17}$ trials. The original purpose in some of the included trials was not to investigate the effect of pioglitazone on cardiovascular events. Third, the definition of MACE differed among available trials. Some trials $^{8}{ }^{9}$ reported composite of myocardial infarction and stroke while others ${ }^{11} 13141719$ reported non-fatal myocardial infarction, non-fatal stroke and vascular death as major vascular events. Since fatal myocardial infarction and fatal stroke are likely the major components of cardiovascular death, the end points categorised as major cardiovascular events among available trials may not be substantially different. Fourth, the populations and frequency of medication use, especially statins, differed across trials. Since our study was a study-level meta-analysis, the issues mentioned above may not be well-settled. Individual-level pooled analyses of relevant trials could provide additional insights. Finally, TSA showed that the required information sizes were not achieved for most end points.

In summary, the current meta-analysis of completed, randomised clinical trials indicates that pioglitazone has beneficial effects in reducing the risk of MACE in people with insulin resistance, pre-diabetes and type 2 diabetes mellitus. Rates of heart failure, bone fracture, weight gain and oedema increased in pioglitazonetreated patients, while the occurrences of cancer and allcause mortality did not rise. Weighing the risk-benefit profile, treatment with pioglitazone may be a reasonable choice in appropriately selected patients with insulin resistance, pre-diabetes and type 2 diabetes mellitus.

\section{Author affiliations}

${ }^{1}$ Jia-Yi Clinic, Taoyuan, Taiwan

${ }^{2}$ UCLA Stroke Center, Los Angeles, California, USA

${ }^{3}$ Department of Neurology, Research Services Center for Health Information, Chang Gung University, Taoyuan, Taiwan

${ }^{4}$ Department of Nephrology, School of Medicine, College of Medicine, Taipei Medical University, Wan Fang Hospital, Taipei, Taiwan

${ }^{5}$ Department of Neurology, Chang Gung University College of Medicine, Chang Gung Memorial Hospital, Chiayi, Taiwan

${ }^{6}$ Department of Neurology, Medical University of South Carolina, Charleston, South Carolina, USA

Contributors H-WL acquisition of data, analysis and interpretation of data wrote the first draft. JLS analysis and interpretation of data, critical revision of manuscript for intellectual content. Y-LW acquisition of data, critical revision of manuscript for intellectual content. T-HC critical revision of manuscript for intellectual content. ML study concept and design, acquisition of data, 
analysis and interpretation of data, critical revision of manuscript for intellectual content. BO study supervision, critical revision of manuscript for intellectual content.

Funding This work was supported by Ministry of Science and Technology, Taiwan, grant number: MOST104-2314-B-182-019 and MOST105-2628-B-182-008-MY2.

Competing interests None declared.

Ethics approval This is a meta-analysis based on published articles.

Provenance and peer review Not commissioned; externally peer reviewed.

Data sharing statement No additional data are available.

Open Access This is an Open Access article distributed in accordance with the Creative Commons Attribution Non Commercial (CC BY-NC 4.0) license, which permits others to distribute, remix, adapt, build upon this work noncommercially, and license their derivative works on different terms, provided the original work is properly cited and the use is non-commercial. See: http:// creativecommons.org/licenses/by-nc/4.0/

\section{REFERENCES}

1. Shah AD, Langenberg C, Rapsomaniki E, et al. Type 2 diabetes and incidence of cardiovascular diseases: a cohort study in 1.9 million people. Lancet Diabetes Endocrinol 2015;3:105-13.

2. Lee M, Saver JL, Hong KS, et al. Effect of pre-diabetes on future risk of stroke: meta-analysis. BMJ 2012;344:e3564

3. Kernan WN, Inzucchi SE, Viscoli CM, et al. Insulin resistance and risk for stroke. Neurology 2002;59:809-15.

4. Bonora E, Formentini G, Calcaterra F, et al. HOMA-estimated insulin resistance is an independent predictor of cardiovascular disease in type 2 diabetic subjects: prospective data from the Verona diabetes complications study. Diabetes Care 2002;25:1135-41.

5. Schernthaner G, Currie CJ, Schernthaner GH. Do we still need pioglitazone for the treatment of type 2 diabetes? A risk-benefit critique in 2013. Diabetes Care 2013;36(Suppl 2):S155-161.

6. Di Pino A, Urbano F, Zagami RM, et al. Low endogenous secretory receptor for advanced glycation end-products levels are associated with inflammation and carotid atherosclerosis in pre-diabetes. J Clin Endocrinol Metab 2016;101:1701-9.

7. Lincoff AM, Wolski K, Nicholls SJ, et al. Pioglitazone and risk of cardiovascular events in patients with type 2 diabetes mellitus: a meta-analysis of randomized trials. JAMA 2007;298:1180-8.

8. DeFronzo RA, Tripathy D, Schwenke DC, et al. Pioglitazone for diabetes prevention in impaired glucose tolerance. $N$ Engl J Med 2011;364:1104-15.

9. Kernan WN, Viscoli CM, Furie $\mathrm{KL}$, et al. Pioglitazone after ischemic stroke or transient ischemic attack. $N$ Engl J Med 2016;374:1321-31.

10. Tanaka R, Yamashiro K, Okuma Y, et al. Effects of pioglitazone for secondary stroke prevention in patients with impaired glucose tolerance and newly diagnosed diabetes: the J-SPIRIT study. $J$ Atheroscler Thromb 2015;22:1305-16.

11. Kaku K, Daida H, Kashiwagi A, et al. Long-term effects of pioglitazone in Japanese patients with type 2 diabetes without a recent history of macrovascular morbidity. Curr Med Res Opin 2009;25:2925-32.

12. Lee HW, Lee HC, Kim BW, et al. Effects of low dose pioglitazone on restenosis and coronary atherosclerosis in diabetic patients undergoing drug eluting stent implantation. Yonsei Med $\mathrm{J}$ 2013;54:1313-20

13. Nissen SE, Nicholls SJ, Wolski K, et al. Comparison of pioglitazone vs glimepiride on progression of coronary atherosclerosis in patients with type 2 diabetes: the PERISCOPE randomized controlled trial JAMA 2008;299:1561-73.

14. Yoshii H, Onuma T, Yamazaki T, et al. Effects of pioglitazone on macrovascular events in patients with type 2 diabetes mellitus at high risk of stroke: the PROFIT-J study. J Atheroscler Thromb 2014;21:563-73.

15. Moher D, Liberati A, Tetzlaff $\mathrm{J}$, et al. Preferred reporting items for systematic reviews and meta-analyses: the PRISMA statement. BMJ 2009;339:b2535

16. Wetterslev J, Thorlund $\mathrm{K}$, Brok J, et al. Trial sequential analysis may establish when firm evidence is reached in cumulative meta-analysis. J Clin Epidemiol 2008;61:64-75.

17. Dormandy JA, Charbonnel B, Eckland DJ, et al. Secondary prevention of macrovascular events in patients with type 2 diabetes in the PROactive study (prospective pioglitazone clinical trial in macrovascular events): a randomised controlled trial. Lancet 2005;366:1279-89.

18. Genovese $S$, Passaro A, Brunetti $P$, et al. Pioglitazone randomised Italian study on metabolic syndrome (PRISMA): effect of pioglitazone with metformin on HDL-c levels in type 2 diabetic patients. J Endocrinol Invest 2013;36:606-16.

19. Mazzone T, Meyer PM, Feinstein SB, et al. Effect of pioglitazone compared with glimepiride on carotid intima-media thickness in type 2 diabetes: a randomized trial. JAMA 2006;296:2572-81.

20. Wilcox R, Bousser MG, Betteridge DJ, et al. Effects of pioglitazone in patients with type 2 diabetes with or without previous stroke: results from PROactive (prospective pioglitazone clinical trial in macrovascular events 04). Stroke 2007;38:865-73.

21. Gerstein HC, Bosch J, Dagenais GR, et al. Basal insulin and cardiovascular and other outcomes in dysglycemia. $N$ Engl J Med 2012;367:319-28

22. Varvaki Rados D, Catani Pinto L, Reck Remonti L, et al. The association between sulfonylurea use and all-cause and cardiovascular mortality: a meta-analysis with trial sequential analysis of randomized clinical trials. PLoS Med 2016;13:e1001992.

23. Scirica BM, Braunwald E, Bhatt DL. Saxagliptin, alogliptin, and cardiovascular outcomes. N Engl J Med 2014;370:483-4.

24. Libby P, Ridker PM, Hansson GK. Progress and challenges in translating the biology of atherosclerosis. Nature 2011;473:317-25

25. Nicholls SJ, Tuzcu EM, Wolski K, et al. Lowering the triglyceride/ high-density lipoprotein cholesterol ratio is associated with the beneficial impact of pioglitazone on progression of coronary atherosclerosis in diabetic patients: insights from the PERISCOPE (pioglitazone effect on regression of intravascular sonographic coronary obstruction prospective evaluation) study. J Am Coll Cardiol 2011;57:153-9.

26. Rohatgi A, Khera A, Berry JD, et al. HDL cholesterol efflux capacity and incident cardiovascular events. $N$ Engl J Med 2014;371:2383-93.

27. Khera AV, Cuchel M, de la Llera-Moya M, et al. Cholesterol efflux capacity, high-density lipoprotein function, and atherosclerosis. N Engl J Med 2011;364:127-35.

28. Mizoguchi M, Tahara N, Tahara A, et al. Pioglitazone attenuates atherosclerotic plaque inflammation in patients with impaired glucose tolerance or diabetes a prospective, randomized, comparator-controlled study using serial FDG PET/CT imaging study of carotid artery and ascending aorta. JACC Cardiovasc Imaging 2011;4:1110-18.

29. Nissen SE, Wolski K. Effect of rosiglitazone on the risk of myocardial infarction and death from cardiovascular causes. N Engl J Med 2007;356:2457-71.

30. Selvin E, Bolen S, Yeh HC, et al. Cardiovascular outcomes in trials of oral diabetes medications: a systematic review. Arch Intern Med 2008;168:2070-80.

31. Billington EO, Grey A, Bolland MJ. The effect of thiazolidinediones on bone mineral density and bone turnover: systematic review and meta-analysis. Diabetologia 2015;58:2238-46.

32. Zhu ZN, Jiang YF, Ding T. Risk of fracture with thiazolidinediones: an updated meta-analysis of randomized clinical trials. Bone 2014;68:115-23.

33. Colhoun HM, Livingstone SJ, Looker HC, et al. Hospitalised hip fracture risk with rosiglitazone and pioglitazone use compared with other glucose-lowering drugs. Diabetologia 2012;55:2929-37.

34. Peters JM, Shah YM, Gonzalez FJ. The role of peroxisome proliferator-activated receptors in carcinogenesis and chemoprevention. Nat Rev Cancer 2012;12:181-95.

35. Azoulay L, Yin H, Filion KB, et al. The use of pioglitazone and the risk of bladder cancer in people with type 2 diabetes: nested casecontrol study. BMJ 2012;344:e3645.

36. Tuccori $\mathrm{M}$, Filion $\mathrm{KB}$, Yin $\mathrm{H}$, et al. Pioglitazone use and risk of bladder cancer: population based cohort study. BMJ 2016;352 i1541.

37. Ferwana M, Firwana B, Hasan $\mathrm{R}$, et al. Pioglitazone and risk of bladder cancer: a meta-analysis of controlled studies. Diabetic Med 2013;30:1026-32

38. Ferrara A, Lewis JD, Quesenberry CP, Jr., et al. Cohort study of pioglitazone and cancer incidence in patients with diabetes. Diabetes Care 2011;34:923-9.

39. Lewis JD, Habel LA, Quesenberry CP, et al. Pioglitazone use and risk of bladder cancer and other common cancers in persons with diabetes. JAMA 2015;314:265-77.

40. Stevens JW, Khunti K, Harvey R, et al. Preventing the progression to type 2 diabetes mellitus in adults at high risk: a systematic review and network meta-analysis of lifestyle, pharmacological and surgical interventions. Diabetes Res Clin Pract 2015;107:320-31. 